University of Nebraska - Lincoln

DigitalCommons@University of Nebraska - Lincoln

Agronomy \& Horticulture -- Faculty Publications

Agronomy and Horticulture Department

3-2002

\title{
Agroecosystems, Nitrogen-use Efficiency, and Nitrogen Management
}

Kenneth G. Cassman

University of Nebraska-Lincoln, kcassman1@unl.edu

Achim R. Dobermann

University of Nebraska-Lincoln, adobermann2@unl.edu

Daniel T. Walters

University of Nebraska-Lincoln, dwalters1@unl.edu

Follow this and additional works at: https://digitalcommons.unl.edu/agronomyfacpub

Part of the Plant Sciences Commons

Cassman, Kenneth G.; Dobermann, Achim R.; and Walters, Daniel T., "Agroecosystems, Nitrogen-use Efficiency, and Nitrogen Management" (2002). Agronomy \& Horticulture -- Faculty Publications. 356. https://digitalcommons.unl.edu/agronomyfacpub/356

This Article is brought to you for free and open access by the Agronomy and Horticulture Department at DigitalCommons@University of Nebraska - Lincoln. It has been accepted for inclusion in Agronomy \& Horticulture -Faculty Publications by an authorized administrator of DigitalCommons@University of Nebraska - Lincoln. 


\section{Agroecosystems, Nitrogen-use Efficiency, and Nitrogen Management}

The global challenge of meeting increased food demand and protecting environmental quality will be won or lost in cropping systems that produce maize, rice, and wheat. Achieving synchrony between $\mathrm{N}$ supply and crop demand without excess or deficiency is the key to optimizing tradeoffs amongst yield, profit, and environmental protection in both large-scale systems in developed countries and smallscale systems in developing countries. Setting the research agenda and developing effective policies to meet this challenge requires quantitative understanding of current levels of $\mathrm{N}$-use efficiency and losses in these systems, the biophysical controls on these factors, and the economic returns from adoption of improved management practices. Although advances in basic biology, ecology, and biogeochemistry can provide answers, the magnitude of the scientific challenge should not be underestimated because it becomes increasingly difficult to control the fate of $\mathrm{N}$ in cropping systems that must sustain yield increases on the world's limited supply of productive farm land.

\section{INTRODUCTION}

The focus of this paper is on nitrogen-use efficiency (NUE) in cereal production systems because maize (Zea mays L.), rice (Oryza sativa L.), and wheat (Triticum aestivum L.) provide more than $60 \%$ of human dietary calories either as cereals for direct human consumption or embodied in livestock products produced from animals fed with feed grains and their by-products (http:/apps.fao.org/, agricultural production). It is likely that these same cereal crops will continue to account for the bulk of the future human food supply because they produce greater yields of human-edible food, are easily grown, stored, and transported, and require less fuel and labor for processing and cooking than other food crops. Our analysis will examine the NUE of these primary cereals in the world's major cropping systems, which also account for the majority of global $\mathrm{N}$ fertilizer use. We define the NUE of a cropping system as the proportion of all $\mathrm{N}$ inputs that are removed in harvested crop biomass, contained in recycled crop residues, and incorporated into soil organic matter and inorganic $\mathrm{N}$ pools. Nitrogen not recovered in these $\mathrm{N}$ sinks is lost from the cropping system and thus contributes to the reactive $\mathrm{N}(\mathrm{Nr})$ (1) load that cascades through environments external to the agroecosystem.

Our evaluation will focus on NUE in on-farm settings because estimates of NUE from experimental plots do not accurately represent the efficiencies achieved in farmers' fields. This lack of agreement results from differences in the scale of farming operations and differences in $\mathrm{N}$-management practices-some of which are only feasible in small research plots. The effect of scale not only influences $\mathrm{N}$ fertilizer application, but all other management operations such as tillage, seeding, weed and pest management, irrigation, and harvest, which also affect efficiency. As a result, $\mathrm{N}$-fertilizer efficiency in well-managed research experiments is generally greater than the efficiency of the same practices applied by farmers in production fields. For example, the average $\mathrm{N}$-fertilizer uptake efficiency (defined as the percent- age of fertilizer-N recovered in aboveground plant biomass during the growing season-hereafter called the N-fertilizer recovery efficiency $-\mathrm{RE}_{\mathrm{N}}$ ), achieved by rice farmers is $31 \%$ of applied $\mathrm{N}$ based upon on-farm measurements in the major rice-production regions of four Asian countries (Table 1). In contrast, $\mathrm{RE}_{\mathrm{N}}$ for rice in well-managed field experiments typically range from $50-80 \%$ (3-5). In the authors' experience, similar overestimation of $\mathrm{RE}_{\mathrm{N}}$ in small plot experiments occurs for irrigated and rain-fed maize in the North-Central USA and for irrigated wheat in California.

The need to improve $\mathrm{RE}_{\mathrm{N}}$ will be emphasized because $\mathrm{N}$ fertilizer is the largest source of $\mathrm{N}$ input to and losses from cereal cropping systems. A recent study estimates total $\mathrm{N}$ input to the world's cropland at $169 \mathrm{Tg} \mathrm{N} \mathrm{yr}^{-1}$ (6). Inorganic $\mathrm{N}$ fertilizer, biological $\mathrm{N}$ fixation from legumes and other $\mathrm{N}$-fixing organisms, atmospheric deposition, animal manures, and crop residues account for $46 \%, 20 \%, 12 \%, 11 \%$, and $7 \%$, respectively, of this total. Hence, crop-management practices that increase $\mathrm{RE}_{\mathrm{N}}$ have a substantial impact on the amount of $\mathrm{Nr}$ that escapes from cereal production systems. While we recognize that solutions to global concerns about effects of $\mathrm{Nr}$ on the environment must involve integrated management of both inorganic and organic $\mathrm{N}$ sources to maximize NUE, other papers in this issue of Ambio and elsewhere address issues of $\mathrm{N}$ efficiency in livestock production systems and the contributions of organic $\mathrm{N}$ sources such as legume crops and green manures $(6,7)$.

\section{NITROGEN-USE EFFICIENCY TODAY}

Applied N not taken up by the crop or immobilized in soil organic $\mathrm{N}$ pools-which include both microbial biomass and soil organic matter-is vulnerable to losses from volatilization, denitrification, and leaching. The overall NUE of a cropping system can therefore be increased by achieving greater uptake efficiency from applied $\mathrm{N}$ inputs, by reducing the amount of $\mathrm{N}$ lost from soil organic and inorganic $\mathrm{N}$ pools, or both. In many cropping systems, the size of the organic and inorganic $\mathrm{N}$ pools has reached steady-state or is changing very slowly, and the $\mathrm{N}$ inputs from biological $\mathrm{N}_{2}$ fixation and atmospheric deposition are relatively constant. For example, analysis of the $\mathrm{N}$ balance in long-term experiments on irrigated rice in Asia suggests that many of these systems have reached steady-state (8), and similar evidence suggests that some maize-based cropping systems in the USA corn belt are also near steady-state (9). In these cases, the overall NUE of a cereal cropping system is equal to the $R E_{N}$.

In contrast to systems at steady-state, adoption of new management practices or crop rotations that affect the soil carbon (C) balance will also affect the $\mathrm{N}$ balance because the $\mathrm{C} / \mathrm{N}$ ratio of soil organic matter is relatively constant. In such cropping systems, the overall NUE of the cropping system must include changes in the size of soil organic and inorganic $\mathrm{N}$ pools in addition to the $\mathrm{RE}_{\mathrm{N}}$. When soil-N content is increasing, the amount of sequestered $\mathrm{N}$ contributes to a higher NUE of the cropping system, and the amount of sequestered $\mathrm{N}$ derived from applied $\mathrm{N}$ contributes to a higher $\mathrm{RE}_{\mathrm{N}}$. Conversely, any decrease in soil$\mathrm{N}$ stocks will reduce NUE and $\mathrm{RE}_{\mathrm{N}}$.

Unfortunately, there is a paucity of reliable data on $\mathrm{RE}_{\mathrm{N}}$ based 
on measurements from on-farm studies in the major cereal production systems. Likewise, we are not aware of measurements of on-farm NUE that include the contributions from both $\mathrm{RE}_{\mathrm{N}}$ and changes in soil-N reserves. This shortage of information reflects the logistical difficulty and high cost of obtaining direct on-farm measurements and the lack of funding for what appear to be routine on-farm evaluations. Available data indicate a very low mean $\mathrm{RE}_{\mathrm{N}}$ of $31 \%$ in continuous irrigated rice systems in Asia $(2,10)$, and somewhat higher efficiency of $37 \%$ for maize in the major maize-producing states of the USA (Table 1). In contrast, mean $\mathrm{RE}_{\mathrm{N}}$ for wheat in rice-wheat systems of India was $18 \%$ in one year and $49 \%$ the next. This difference was associated with low grain yields in the first year caused by unfavorable weather, and highlights the importance of robust crop growth and yield to greater $\mathrm{RE}_{\mathrm{N}}$. Good crop management and high yields of rain-fed wheat in northwestern Europe also contribute to relatively high $\mathrm{RE}_{\mathrm{N}}$ in those systems (11). Most other estimates of $\mathrm{RE}_{\mathrm{N}}$ in the literature are obtained from experimental plots at research stations, which tend to overestimate $R_{N}$ for the reasons previously described.

Two methods are commonly used for direct measurement of $\mathrm{RE}_{\mathrm{N}}$, and both have inherent weaknesses (12). The 'N-difference' method is based on the difference in $\mathrm{N}$ uptake between a crop that receives a given amount of applied $\mathrm{N}$ and $\mathrm{N}$ uptake in a reference plot without applied N. Another technique uses ${ }^{15} \mathrm{~N}$ labeled fertilizer to estimate crop recovery of applied N. Each of these methods can be confounded by 'added-N effects' when the applied $\mathrm{N}$ alters the ability of the plant root system to acquire $\mathrm{N}$ from soil, the rate of net $\mathrm{N}$ mineralization from organic $\mathrm{N}$ pools, or both. In addition, the ${ }^{15} \mathrm{~N}$-fertilizer technique can also be confounded by 'pool substitution' whereby $\mathrm{N}$ from applied ${ }^{15} \mathrm{~N}$-fertilizer replaces $\mathrm{N}$ in the various soil $\mathrm{N}$ pools during the processes of $\mathrm{N}$ immobilization-mineralization turnover from or- ganic matter and microbial biomass. Because estimates of $R_{N}$ by the N-difference method are influenced by fewer confounding factors, we believe it is preferable to the ${ }^{15} \mathrm{~N}$-fertilizer technique. The data in Table 1 and cited throughout this paper are based on this method.

The NUE of agricultural systems also have been calculated using aggregate databases on crop production statistics and literature-based assumptions about $\mathrm{N}$ cycling to estimate $\mathrm{N}$ inputs and outputs on a regional or global basis. For example, Smil's (6) elegant global $\mathrm{N}$ balance for crop production estimates an average $\mathrm{N}$ recovery efficiency in crop biomass of $50 \%$ from all sources of $\mathrm{N}$ input-including fertilizers, atmospheric deposition, biological $\mathrm{N}_{2}$ fixation, recycled crop residues, and manures. However, $\mathrm{N}$ recovery efficiencies can differ substantially from each of these $\mathrm{N}$ sources, and therefore it is not possible to estimate $\mathrm{RE}_{\mathrm{N}}$ by this approach. The much lower estimates of $\mathrm{RE}_{\mathrm{N}}$ based upon direct on-farm measurements for rice in Asia and maize in the North-Central USA (Table 1) may reflect higher $\mathrm{N}$ uptake efficiency from indigenous $\mathrm{N}$ sources than from applied fertilizer. Moreover, the overall NUE of these systems would be higher or lower depending on whether soil $\mathrm{N}$ reserves are increasing or decreasing over time.

In recent years, significant strides towards increasing $R_{N}$ are suggested from aggregate data of fertilizer use and crop yields. Since the early 1980s, the ratio of crop yield per unit of applied $\mathrm{N}$ fertilizer (called the partial factor productivity for $\mathrm{N}$ fertilizer- $-\mathrm{PFP}_{\mathrm{N}}$ ) has increased in Japan (13), and the USA (14). For USA maize, $\mathrm{PFP}_{\mathrm{N}}$ increased by $36 \%$ in the last 21 years, from $42 \mathrm{~kg} \mathrm{~kg}^{-1}$ in 1980 to $57 \mathrm{~kg} \mathrm{~kg}^{-1}$ in 2000 (Fig. 1). Because crop dry matter accumulation and grain yield are closely correlated with $\mathrm{N}$ uptake, the increase in $\mathrm{PFP}_{\mathrm{N}}$ since 1980 suggests an associated increase in $\mathrm{RE}_{\mathrm{N}}$ - assuming the indigenous $\mathrm{N}$ supply from net mineralization of soil organic matter, atmospheric $\mathrm{N}$ inputs, and biological $\mathrm{N}$ fixation have remained relatively constant during this period. In contrast, there appears to have been little improvement in $\mathrm{RE}_{\mathrm{N}}$ of irrigated rice in tropical Asia; on-farm efficiencies measured in the late 1960s and early 1970s (15) are comparable to estimates made in the late 1990s as given in Table 1. Understanding the reasons for these trends in $\mathrm{PFP}_{\mathrm{N}}$ and $\mathrm{RE}_{\mathrm{N}}$ and the prognosis for improving them depends on knowledge of the factors that govern $\mathrm{N}$ demand and supply in cereal cropping systems.

\section{BIOPHYSICAL DETERMINANTS OF CROP NITROGEN REQUIREMENTS}

Crop-N demand is determined by biomass yield and the physiological requirements for tissue N. Crop-management practices and climate have the greatest influence on yield. Climate varies considerably from year to year, which causes large differences in yield potential. In irrigated systems, the yield potential of a given crop cultivar is largely governed by solar radiation and temperature. In dryland systems, rainfall amount and temporal distribution also have a large influence on yield potential. While solar radiation, temperature, and moisture regimes determine the genetic yield ceiling, actual crop yields achieved by farmers are generally far below this threshold because it is neither possible, nor economic, to remove all limitations to growth from sub- 
optimal nutrient supply, weed competition, and damage from insects and diseases. Hence, the interaction of climate and management causes tremendous year-to-year variation in on-farm yields and crop $\mathrm{N}$ requirements.

Crop physiological $\mathrm{N}$ requirements are controlled by the efficiency with which $\mathrm{N}$ in the plant is converted to biomass and grain yield. Because cereal crops are harvested for grain, the most relevant measure of physiological $\mathrm{N}$ efficiency $\left(\mathrm{PE}_{\mathrm{N}}\right)$ is the change in grain yield per unit change in $\mathrm{N}$ accumulation in aboveground biomass. Crop- $\mathrm{PE}_{\mathrm{N}}$ is largely governed by 2 factors: $i$ ) the genetically determined mode of photosynthesis - either the $\mathrm{C}_{3}$ or $\mathrm{C}_{4}$ photosynthetic pathway; and $i$ ) the grain $\mathrm{N}$ concentration-also under genetic control but affected by $\mathrm{N}$ supply as well. Both rice and wheat are $\mathrm{C}_{3}$ plants while maize is a $\mathrm{C}_{4}$ plant. The $\mathrm{C}_{4}$ plants tend to have greater $\mathrm{PE}_{\mathrm{N}}$ than $\mathrm{C}_{3}$ plants because the $\mathrm{C}_{4}$ pathway has a higher photosynthetic rate per unit leaf-N content (16), which results in greater biomass production per unit of plant-N accumulation (Fig. 2, ref. 17).

Large genetic variation in grain- $\mathrm{N}$ concentration within each of the major cereal species has allowed plant breeders to develop cultivars with the desired grain-N concentration for specific end-use properties. Relatively low grain-N content of $10-12 \mathrm{~g} \mathrm{~kg}^{-1}$ here and elsewhere, grain$\mathrm{N}$ concentration is given on a dry weight basis desired in rice for optimal cooking and eating quality. Maize-N content also is relatively low (13-14 $\mathrm{g} \mathrm{kg}^{-1}$ ) because maize products for human consumption or animal feed do not require high protein. In contrast, the $\mathrm{N}$ concentration of wheat must exceed $18 \mathrm{~g} \mathrm{~kg}^{-1}$ to have acceptable quality for bread or noodles. The relationship between grain yield and the $\mathrm{N}$ contained in aboveground biomass at physiological maturity provides a measure of $\mathrm{PE}_{\mathrm{N}}$ across a wide range of production environments (Fig. 3). The line at the upper boundary of data points in this Figure provides an estimate of maximum $\mathrm{N}$ dilution in plant biomass, which occurs when $\mathrm{N}$ is the most limiting factor to plant growth. When $\mathrm{N}$ is no longer the most limiting resource and other factors such as water supply, pest damage, or deficiencies of other nutrients reduce crop growth, the amount of grain produced per unit $\mathrm{N}$ uptake decreases and moves off the line of maximum $\mathrm{N}$ dilution.

Across a wide range of production environments and management practices, maize tends to have a larger increase in grain yield per unit $\mathrm{N}$ uptake than rice because it is a $\mathrm{C}_{4}$ plant. This advantage in $\mathrm{PE}_{\mathrm{N}}$ is evident in the slopes of regression lines in Figure 3. Rice has a lower efficiency than maize because it is a $\mathrm{C}_{3}$ plant although its lower grain $\mathrm{N}$ concentration partially offsets this disadvantage. Wheat has the smallest $\mathrm{PE}_{\mathrm{N}}$ of the 3-major cereals because it is a $\mathrm{C}_{3}$ plant with high grain protein (data not shown). Two additional points are noteworthy. First, the lines defining both maximum $\mathrm{N}$ dilution and the overall regression are curvilinear, which means there is a diminishing return to the conversion of plant $\mathrm{N}$ to grain as yields approach the yield
Figure 1. Trends in maize grain yield, use of $\mathbf{N}$ fertilizer, and Partial Factor Productivity from applied $\mathrm{N}$ fertilizer $\left(\mathrm{PFP}_{\mathrm{N}}, \mathrm{kg}\right.$ grain yield $\mathrm{kg}^{-1} \mathrm{~N}$ applied) in the USA.

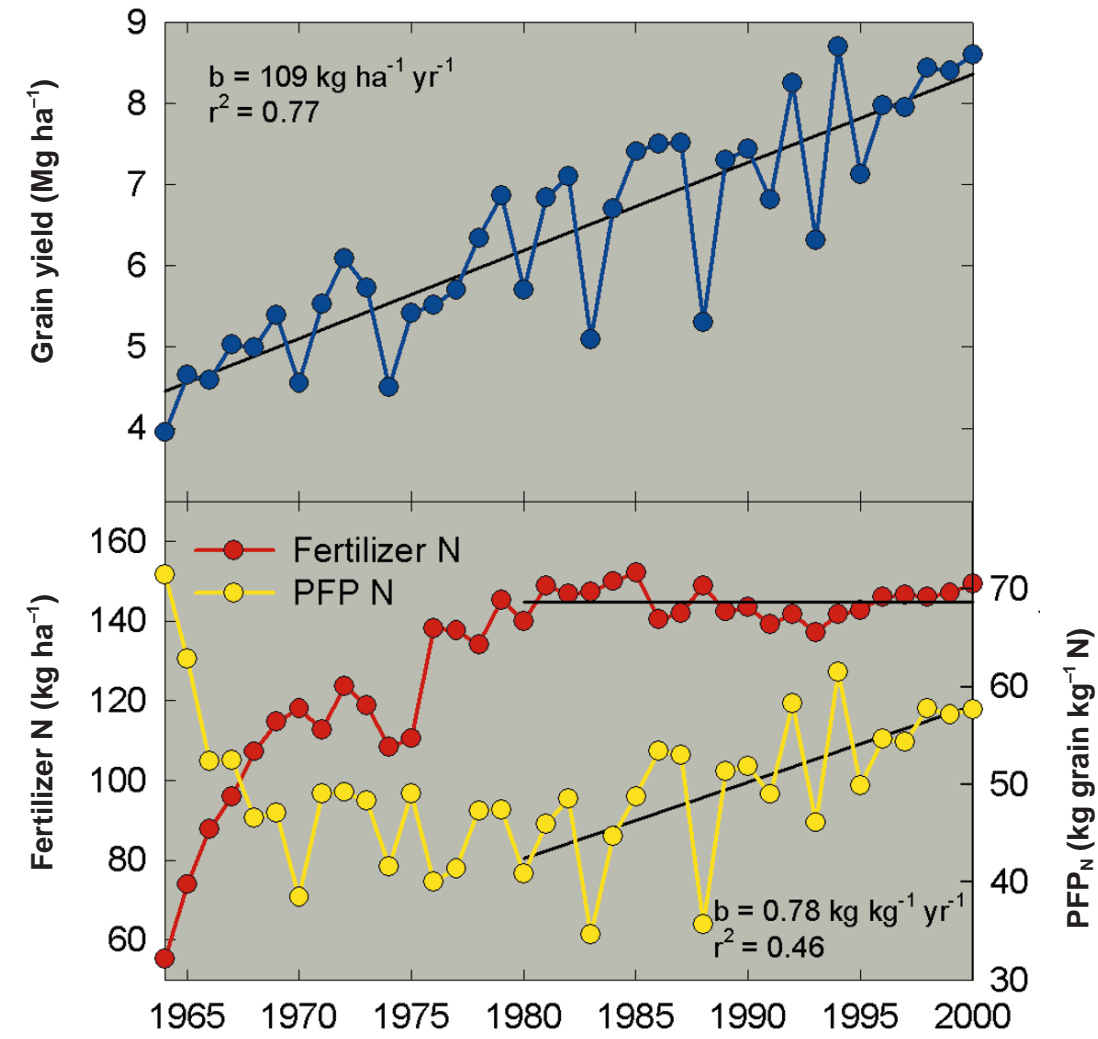

Sources of data: Mean annual maize yields, National Agricultura Statistics Service, USDA http://www.usda.gov/nass/; mean annual $\mathbf{N}$ fertilizer $\mathbf{N}$ use, USDA Annual Cropping Practices Surveys ( $>2000$ farms representing 80 to $90 \%$ of the USA maize area), Economic Research Service, USDA, http:// www.ers.usda.gov

Figure 2. Relationships between dry matter yield and nitrogen content of plant tissue for $C_{3}$ and $C_{4}$ crops. (Source: 17 ).

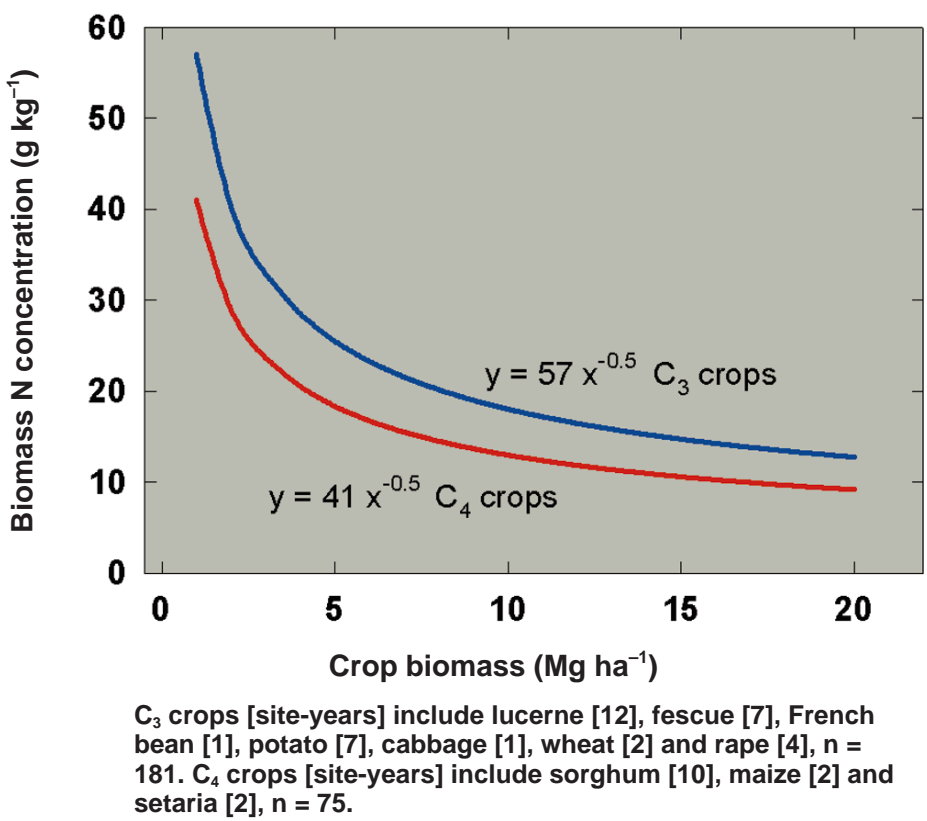




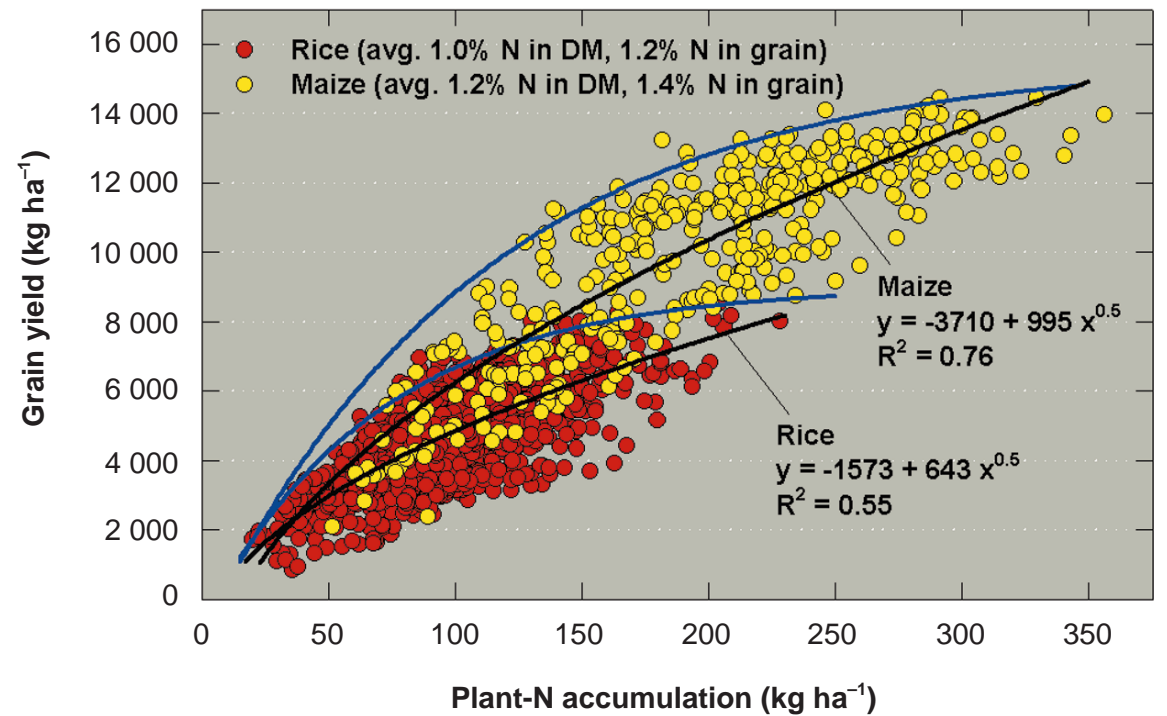

Data sources: $i$ ) for rice, data obtained from onfarm and research station experiments conducted across a wide range of agroecological environments in Asia from 1995 to 2000 ( $n=1658$ ); ii) for maize, data obtained from on-farm and research station experiments conducted across a wide range of agroecological environments in the North-Central USA from 1995 to $2000(n=470)$. Blue lines indicate the boundary of maximum dilution of $\mathrm{N}$ in the plant (maximum physiological efficiency), whereas the black lines depict the average physiological efficiency as obtained from nonlinear regression for the entire data set for maize and rice. potential ceiling. Second, the $\mathrm{N}$ concentration of cereal straw and stover is much smaller than in grain, and differences among cereal crops or among cultivars of the same crop species are relatively small. Therefore, the amount of $\mathrm{N}$ remaining in straw or stover has a relatively small effect on $\mathrm{PE}_{\mathrm{N}}$ unless factors other than $\mathrm{N}$ are limiting crop growth and grain yield.

\section{DYNAMICS OF NITROGEN SUPPLY}

Inorganic nitrate and ammonium ions are the primary source of $\mathrm{N}$ taken up by plant roots. Both indigenous soil resources and applied $\mathrm{N}$ inputs contribute to this plant-available $\mathrm{N}$ pool, which represents a very small fraction of total soil-N. For example, a typical irrigated rice soil in Asia contains about $2800 \mathrm{~kg} \mathrm{~N} \mathrm{ha}^{-1}$ in the top $20 \mathrm{~cm}$ of soil where roots derive the majority of crop-N supply. Of this total, the amount of $\mathrm{N}$ derived from indigenous resources during a single cropping cycle typically ranges from $30-100 \mathrm{~kg} \mathrm{~N} \mathrm{ha}^{-1}$ (Fig. 4a), which represents only $1-4 \%$ of total soil N. For cereal crops, we define the indigenous soil-N supply as the amount of $\mathrm{N}$ the crop obtains from the inorganic $\mathrm{N}$ pool, net $\mathrm{N}$ mineralization from soil organic matter and incorporated crop residues, biological $\mathrm{N}_{2}$ fixation by soil microflora in the rhizosphere and floodwater (in the case of irrigated rice), and inputs of $\mathrm{N}$ from atmospheric deposition and irrigation water. Similarly, total-N in the top $20 \mathrm{~cm}$ of a fertile prairie soil in the USA corn belt is about $4000 \mathrm{~kg} \mathrm{~N} \mathrm{ha}^{-1}$, and the indigenous $\mathrm{N}$ supply typically ranges from $80-240 \mathrm{~kg} \mathrm{~N} \mathrm{ha}^{-1}$ (Fig. $4 \mathrm{~b}$ ), which is $2-6 \%$ of total soil-N. Although small in size, the indigenous $\mathrm{N}$ supply has a very high $\mathrm{N}$-fertilizer substitution value because of the relatively low $\mathrm{RE}_{\mathrm{N}}$ from applied $\mathrm{N}$ fertilizer.

A maize crop that produces a grain yield of $10000 \mathrm{~kg}$ ha ${ }^{1}$ requires total uptake of about $190 \mathrm{~kg} \mathrm{~N} \mathrm{ha}^{-1}$ (Fig. 3). The indigenous $\mathrm{N}$ supply typically provides about $130 \mathrm{~kg} \mathrm{~N} \mathrm{ha}^{-1}$ (median value in Fig. 4b), which leaves $60 \mathrm{~kg} \mathrm{~N} \mathrm{ha}^{-1}$ that must be provided by applied N. If $\mathrm{RE}_{\mathrm{N}}$ is $37 \%$, which is typical of on-farm conditions (Table 1 ), then an $\mathrm{N}$-fertilizer rate of $162 \mathrm{~kg} \mathrm{~N} \mathrm{ha}^{-1}$ must be applied to meet crop- $\mathrm{N}$ demand. If the indigenous $\mathrm{N}$ supply decreases from 130 to $100 \mathrm{~kg} \mathrm{~N}$ $\mathrm{ha}^{-1}$ (a 23\% reduction), then the N-fertilizer requirement increases by $50 \%$ to $243 \mathrm{~kg} \mathrm{~N}^{-1}$, assuming $\mathrm{RE}_{\mathrm{N}}$ remains constant at this higher $\mathrm{N}$ fertilizer rate. However, $\mathrm{RE}_{\mathrm{N}}$ typically
Figure 4. Variation in the indigenous $\mathrm{N}$ supply $\left(\mathrm{I}_{\mathrm{N}}\right.$, plant $\mathrm{N}$ accumulation in on-farm plots that did not receive $\mathbf{N}$ fertilizer). of a. rice fields in Asia; and b. maize fields in the North-Central USA.

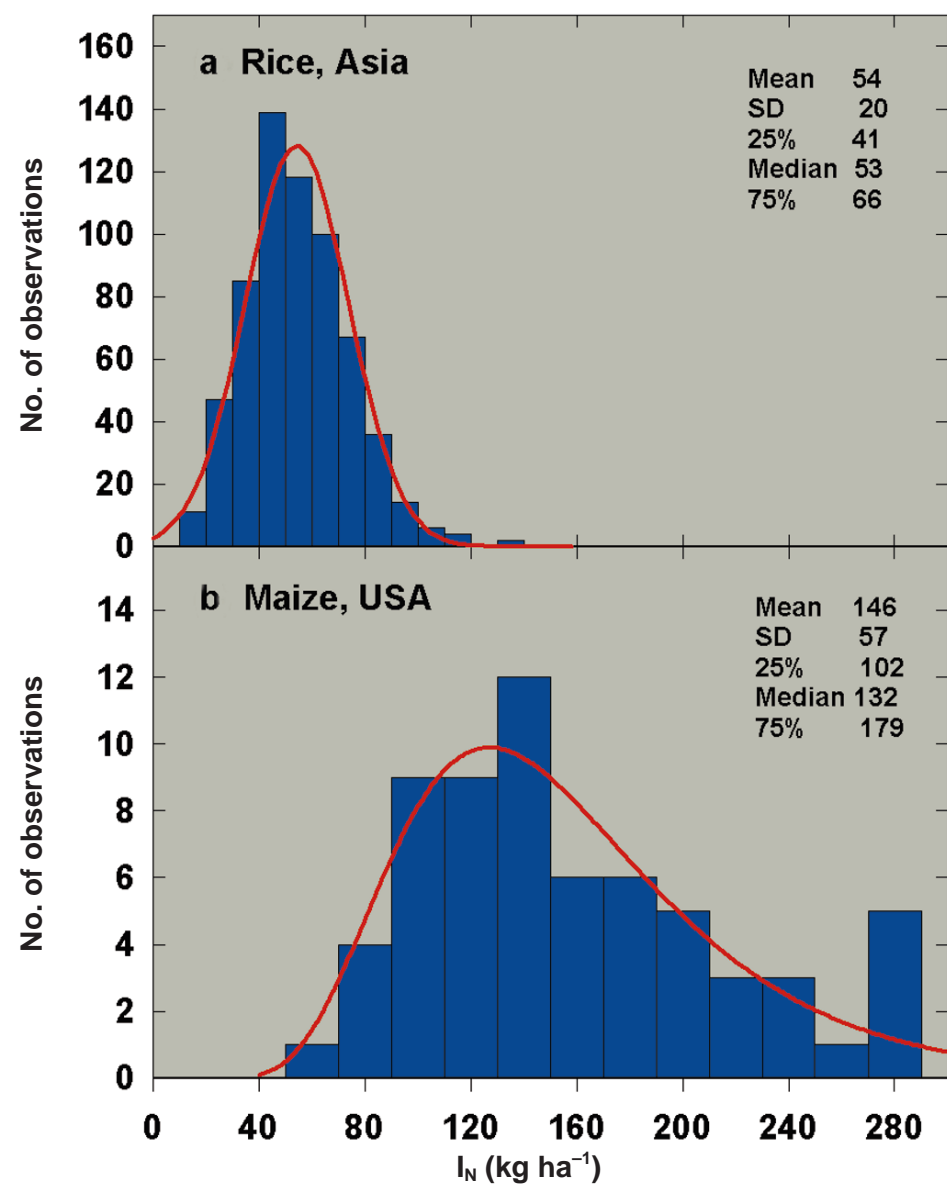

$I_{N}$ for rice was measured at on-farm sites at 179 locations in South and Southeast Asia (Source: C. Witt and A. Dobermann, Reversing Trends of Declining Productivity in Intensive Irrigated Rice Systems, On-farm Monitoring Database, June 2000 release; IRRI, Los Banos, Philippines). $I_{N}$ for maize was measured at 64 loca-

tions in 6 major maize-producing states in the North-Central USA in replicated field experiments and on-farm trials (Source: $D$. Walters, Univ. of Nebraska; North Central regional Research Project $N C-218$ ). For both rice and maize, the $I_{N}$ at each site was measured as described in the footnotes to Table 1. For comparison, mean total soil $\mathrm{N}$ content in the $0-20 \mathrm{~cm}$ topsoil layer was $1.4 \pm 0.7$ $\mathrm{g} \mathrm{kg}^{-1}$ at the rice sites in Asia and $1.6 \pm 0.1 \mathrm{~g} \mathrm{~kg}^{-1}$ at the maize sites in North America. 
decreases as the amount of $\mathrm{N}$-fertilizer application increases (18), especially at high rates of fertilizer input, which further increases the fertilizer substitution value of indigenous $\mathrm{N}$.

Given the large N-fertilizer substitution value of indigenous $\mathrm{N}$, predicting the amount and temporal variation of the indigenous $\mathrm{N}$ supply during crop growth is essential for determining the optimal timing and amount of $\mathrm{N}$-fertilizer applications. Accurate prediction is difficult, however, because the indigenous $\mathrm{N}$ supply is highly variable in the same field over time as well as in different fields within the same agroecological zone, even when the fields have similar soil type, management, and climatic conditions $(3,19)$. This high degree of variability is illustrated by the on-farm measurements of the indigenous $\mathrm{N}$ supply in riceand maize systems (Fig. 4 a, b). Because of the high degree of variation and small size relative to the much larger background of total soil-N, prediction of the indigenous soil $\mathrm{N}$ supply is one of the key challenges for agronomic research.

The primary determinants of total plant-available $\mathrm{N}$ supply are the net rate of $\mathrm{N}$ release from soil organic matter and incorporated crop residues, which is controlled by the balance between $\mathrm{N}$ immobilization and mineralization as mediated by soil microbes, the contributions from applied organic and inorganic $\mathrm{N}$ sources, and losses from the plant-available $\mathrm{N}$ pool. Other contributions include wet/dry deposition from rainfall and dust, freeliving biological $\mathrm{N}$ fixation (BNF), and, in irrigated systems, $\mathrm{N}$ contained in irrigation water. The contribution of BNF is of greatest importance in rice systems with an active floodwater flora and contributions typically range from about 30 to $50 \mathrm{~kg}$ $\mathrm{N} \mathrm{ha}^{-1} \mathrm{crop}^{-1}(20)$. Although there is often a flush of $\mathrm{N}$ mineralization after soil tillage, soil rewetting after a tropical dry season, or after thawing and warming in a temperate spring planting season, the rate of $\mathrm{N}$ mineralization is relatively constant during the period of active crop uptake. In contrast, most $\mathrm{N}$ fertilizers rapidly enter the plant-available $\mathrm{N}$ pool because they are composed of inorganic $\mathrm{N}$ in the form of nitrate, ammonium, or both. The amount and time course of available N-released from organic manures and other organic $\mathrm{N}$ sources depends on the amount of inorganic $\mathrm{N}$ they contain at the time of application and on subsequent rates of $\mathrm{N}$ mineralization. Regardless of $\mathrm{N}$ source, the potential for $\mathrm{N}$ losses is greatest whenever the size of the plant-available $\mathrm{N}$ pool exceeds crop uptake requirements.

Environmental conditions and crop management heavily influence the rate of net $\mathrm{N}$ mineralization from indigenous and applied organic $\mathrm{N}$ as well as the rate of $\mathrm{N}$ losses from the plantavailable N pool. Most influential during the relatively short period of a single crop production cycle are temperature and moisture regime, soil tillage method, and the amount, chemical composition, and timing of carbon and $\mathrm{N}$ inputs from crop residues and roots, inorganic fertilizers, cover crops, and manures. Over longer periods, soil erosion, atmospheric $\mathrm{N}$ deposition, and soil acidification can have large cumulative effects on the overall $\mathrm{N}$ balance and amount of soil-N reserves. A detailed review of these N-supply components and the environmental and management factors that affect ecosystem $\mathrm{N}$ dynamics and $\mathrm{N}$ balance are beyond the scope of this paper. Fortunately, a wealth of information is available in comprehensive reviews on components of the soil-N cycle and the effects of environment and management on $\mathrm{N}$ transformations and fluxes $(12,20-23)$.

At issue here is how well current knowledge of controls on soil-N dynamics is distilled into practical management tools for identifying an $\mathrm{N}$-fertilizer management regime that optimizes $\mathrm{RE}_{\mathrm{N}}$ and profit. While present understanding allows reasonably accurate predictions of the total soil $\mathrm{N}$ balance over long-term periods using mechanistic simulation models (24), such models have not proven sufficiently robust for predicting the size of the available $\mathrm{N}$ pool and crop uptake from it across a wide range of production environments $(25,26)$. The small size of this dynamic $\mathrm{N}$ pool and the complexity of interactive processes that govern its availability over short periods, are difficult issues for realistic models. We would argue that the development of simulation models that can make reasonable predictions of the amount and time course of the indigenous $\mathrm{N}$ supply is a very high priority. However, we also recognize that it will be very challenging to make such models user-friendly for routine N-management decisions.

\section{IMPROVING NITROGEN-USE EFFICIENCY AND PROFIT}

The goal of reducing $\mathrm{Nr}$ while sustaining adequate rates of gain in cereal production to meet expected food demand will require increases in both NUE and $\mathrm{RE}_{\mathrm{N}}$, which in turn will require innovative crop- and soil-management practices. The economic 'benefit to cost ratio' has a large influence on farmer adoption of new technologies. While some management practices might increase NUE by reducing $\mathrm{N}$ losses or increasing the proportion of $\mathrm{N}$ inputs that are retained in soil organic and inorganic $\mathrm{N}$ pools, adoption by farmers is not likely without the promise of adequate economic return. Hence, management options for improving NUE of cereal production systems must also consider $\mathrm{RE}_{\mathrm{N}}$ and $\mathrm{PE}_{\mathrm{N}}$ because these parameters determine the economic impact on grain yield in relation to applied $\mathrm{N}$ inputs and crop$\mathrm{N}$ accumulation.

Recent literature on improving NUE in crop-production systems has emphasized the need for greater synchrony between crop $\mathrm{N}$ demand and the $\mathrm{N}$ supply from all sources throughout the growing season $(3,27-30)$. This approach explicitly recognizes the need to efficiently utilize both indigenous and applied $\mathrm{N}$ and is justified by the fact that losses from all N-loss mechanisms increase in proportion to the amount of available $\mathrm{N}$ present in the soil profile at any given time. Hence, uptake efficiency from a single $\mathrm{N}$-fertilizer application typically decreases in proportion to the amount of $\mathrm{N}$-fertilizer applied (18). The same principle applies to available $\mathrm{N}$ derived from organic $\mathrm{N}$ sources such as legume green manures, cover crops and animal manures. Indeed, potential nitrate leaching from manures can be equal or greater than potential losses from inorganic $\mathrm{N}$ fertilizer when the available $\mathrm{N}$ supply from either source exceeds crop demand by similar amounts for comparable time periods $(31,32)$.

Increased yields also can contribute to greater NUE from both indigenous and applied $\mathrm{N}$ sources because fast growing plants have root systems that more effectively exploit available soil resources (33). Crop health, insect and weed management, moisture and temperature regimes, supplies of nutrients other than $\mathrm{N}$, and use of the best adapted cultivar or hybrid all contribute to more efficient uptake of available $\mathrm{N}$ and greater conversion of plant $\mathrm{N}$ to grain yield. Assuming a well-managed crop, $\mathrm{RE}_{\mathrm{N}}$ and profit from applied $\mathrm{N}$ are therefore optimized with the least possible $\mathrm{N}$ losses when the plant-available $\mathrm{N}$ pool is maintained at the minimum size required to meet crop-N requirements at each stage of growth. Too little $\mathrm{N}$ reduces yields and profit while too much $\mathrm{N}$ is vulnerable to losses from leaching, volatilization, and denitrification.

The degree of synchrony between $\mathrm{N}$ supply and demand and its influence on $\mathrm{RE}_{\mathrm{N}}$ can be evaluated quantitatively when $\mathrm{N}$ demand and supply can be measured or estimated. For example, yield level provides an estimate of crop $\mathrm{N}$ demand and the indigenous $\mathrm{N}$ supply can be estimated by $\mathrm{N}$ uptake in plots that do not receive applied N. On-farm experiments with irrigated rice in Asia and maize in the North-Central USA illustrate the interactive effects of these factors across a wide range of environments based on the relationship between $\mathrm{RE}_{\mathrm{N}}$ and an expression that represents the degree of synchrony between $\mathrm{N}$ supply and demand:

$$
\mathrm{F}_{\mathrm{N}} /\left(1-\mathrm{I}_{\mathrm{N}} / \mathrm{U}_{\mathrm{N}}\right)
$$

Eq. 1 
Figure 5. Variation in nitrogen fertilizer uptake efficiency $R E_{N}$.

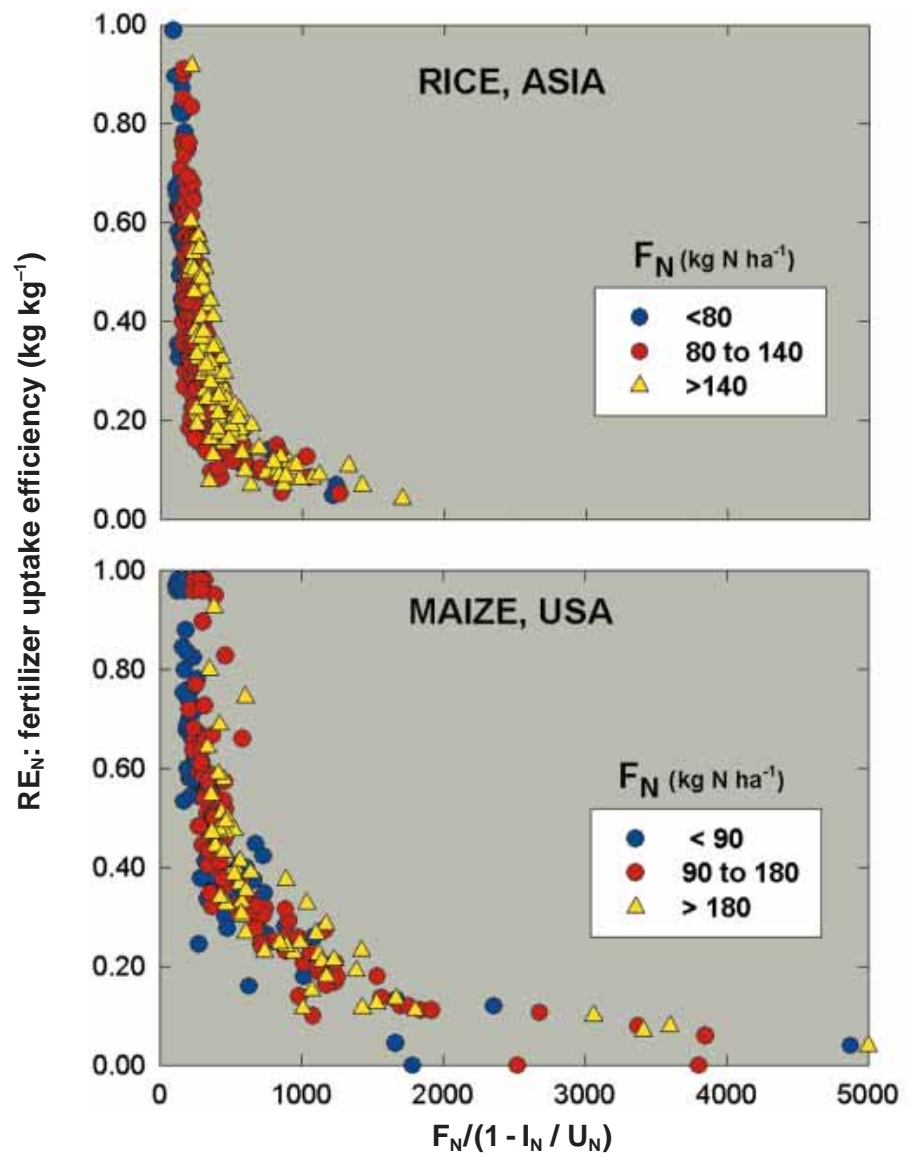

$\left(R E_{N}\right.$ : $k g ~ N$ fertilizer uptake $\mathbf{k g}^{-1} \mathbf{N}$ applied) in relation to the degree of synchrony between crop $N$ demand $\left(U_{N}\right.$ : in $\mathrm{kg} \mathrm{N} \mathrm{ha}^{-1}$ as measured by crop $\mathrm{N}$ accumulation in aboveground biomass at physiological maturity in $\mathrm{N}$ fertilized plots) and the $\mathrm{N}$ supply from indigenous resources $\left(I_{N}\right.$ : in $\mathrm{kg} \mathrm{N} \mathrm{ha}^{-1}$ as measured by crop $\mathrm{N}$ uptake in control plots without applied $\mathrm{N}$ ) and the amount of applied $\mathbf{N}$ fertilizer $\left(F_{N}\right.$ in $\left.\mathrm{kg} \mathrm{N} \mathrm{ha}^{-1}\right)$. Smaller values on the abscissa indicate greater synchrony between $\mathrm{N}$ supply and demand. Data source for rice: C. Witt and A. Dobermann, On-Farm Monitoring Database, June 2000 release; IRRI, Los Banos, Philippines. Data source for maize: D. Walters, University of Nebraska; North Central Regional Research Project NC-218.

where $F_{N}$ is the amount of applied $\mathrm{N}$ fertilizer $\left(\mathrm{kg} \mathrm{N} \mathrm{ha}^{-1}\right), \mathrm{I}_{\mathrm{N}}$ is the indigenous $\mathrm{N}$ supply as measured by crop-N uptake in plots without applied $\mathrm{N}\left(\mathrm{kg} \mathrm{N} \mathrm{ha}^{-1}\right)$, and $\mathrm{U}_{\mathrm{N}}$ is the measured crop- $\mathrm{N}$ uptake $\left(\mathrm{kg} \mathrm{N} \mathrm{ha}^{-1}\right)$ where farmers applied $\mathrm{N}$ fertilizer outside the $\mathrm{N}$-omission plots (Fig. 5). Greater synchrony between supply and demand is indicated by smaller values for this expression. The $\mathrm{RE}_{\mathrm{N}}$ from a given amount of applied $\mathrm{N}$ fertilizer for both crops increases when demand for $\mathrm{N}$ cannot be met by the indigenous $\mathrm{N}$ supply - a situation that occurs when $\mathrm{I}_{\mathrm{N}}$ is small relative to $\mathrm{U}_{\mathrm{N}}$. Conversely, when the indigenous $\mathrm{N}$ supply can meet crop $\mathrm{N}$ requirements $\left(\mathrm{I}_{\mathrm{N}}\right.$ approaches $\left.\mathrm{U}_{N}\right), \mathrm{RE}_{\mathrm{N}}$ is small because $\mathrm{N}$ does not limit crop growth. The data also demonstrate that it is possible to achieve high $\mathrm{RE}_{\mathrm{N}}$ with relatively large $\mathrm{N}$-fertilizer rates $\left(F_{N}\right)$, but only when crop $\mathrm{N}$ demand is much larger than the indigenous supply. The scatter in these relationships reflects the effects of other management factors on crop growth and $\mathrm{N}$ uptake even though $\mathrm{N}$ was generally the most limiting production factor in these on-farm studies.

\section{Improving N Efficiency in USA Maize Systems}

The ' $\mathrm{N}$ synchrony framework' is useful for evaluating management options to improve NUE regardless of scale or technologi- cal sophistication of the crop production system. For example, 3 factors have contributed to improvement since 1980 in $\mathrm{RE}_{\mathrm{N}}$ of USA maize (Fig. 1) where production systems are large scale and highly mechanized: $i$ ) increased yields and more vigorous crop growth associated with increased stress tolerance of modern hybrids (34); ii) improved management of production factors other than $\mathrm{N}$ such as conservation tillage and higher plant densities; and iii) improved N-fertilizer management. Improvements in N-management include significant reductions in fallapplied $\mathrm{N}$-fertilizer with a shift to applications in spring or at planting, greater use of split $\mathrm{N}$-fertilizer applications during the growing season rather than a single large $\mathrm{N}$ application, and development and extension of $\mathrm{N}$-fertilizer recommendations that give $\mathrm{N}$ 'credits' for manure, legume rotations, and residual soil nitrate as determined by soil testing (35).

Each of these practices helps to better match the amount and timing of applied $\mathrm{N}$ to crop- $\mathrm{N}$ demand and the $\mathrm{N}$ supply from indigenous resources. They were developed through large investments in research at land-grant universities during a 30-year period from 1960-1990. Adoption by farmers required additional investments in extension education. Even with this tremendous effort and investment, not all farmers have adopted these practices. Of the total $\mathrm{N}$ fertilizer applied to maize in 1999, 28\% was applied in the fall, $45 \%$ in the spring (preplanting or at planting), and $25 \%$ after planting. Soil testing was practiced on $37 \%$ of the total maize area, and the average number of $\mathrm{N}$-fertilizer applications was 1.8, which means that some farmers still do not use split applications (36). Fall applications continue because $\mathrm{N}$ suppliers offer price discounts for $\mathrm{N}$ applied in the fall. These discounts reflect labor shortage and additional costs for storage, distribution, and application of $\mathrm{N}$ in the spring when many other field operations associated with tillage, planting, and weed control are in progress.

Despite the improvement in efficiency since 1980, our best estimate of average $\mathrm{RE}_{\mathrm{N}}$ in farmer's fields is less than $40 \%$ of the applied N. This estimate is based on recent on-farm measurements in six of the major maize-producing states (Table 1). Eliminating fall applications, increased use of soil testing, and greater use of split applications rather than a single large application would contribute to further gains in efficiency. Continued expansion of no-till and other conservation tillage practices that reduce erosion will also help reduce $\mathrm{N}$ load in surface waters, but they can also increase N-fertilizer losses from denitrification and leaching (37).

\section{Improving N Efficiency in Asian Rice Systems}

In contrast to USA maize production, there is little evidence of improvement in $\mathrm{RE}_{\mathrm{N}}$ of irrigated rice in Asia. Moreover, the rate of increase in yield of irrigated rice has slowed markedly in the past 20 years in part because average yields are approaching the yield potential ceiling in some of the major rice-growing domains (38). Recent studies also document that fertilizer practices used by rice farmers fail to match application amounts with crop demand and soil supply $(2,10,19,39)$. Despite tremendous variation in the indigenous $\mathrm{N}$ supply (Fig. 4), most extension services in developing countries provide a single, standard fertilizer recommendation for an entire district or region. Farmers apparently have few guidelines for adjusting N-fertilizer amount to account for the large differences in the indigenous $\mathrm{N}$ supply, indicating the need for a 'field-specific' approach to $\mathrm{N}$ management.

To test this hypothesis, a field-specific management approach was evaluated in on-farm experiments at 179 sites in 8 rice-producing domains of 6 Asian countries where continuous annual double-crop rice systems were the dominant agricultural land use. Fertilizer application rates for N, phosphorus (P), and potassium $(\mathrm{K})$ were estimated for individual fields by accounting for the indigenous nutrient supply, yield goal, and nutrient de- 
mand as a function of the interactions between uptake requirements for N, P, and K (2). Nitrogen was applied in as many as 4 split applications to better synchronize $\mathrm{N}$ supply with crop demand. A relatively small amount of $\mathrm{N}$ was applied at planting and several topdressings were made during the rapid crop-growth period. The timing of topdressings was determined by monitoring crop-N status with a chlorophyll meter, and the amounts applied were adjusted to meet crop-N demand as determined by the expected yield. The performance of this approach was compared in 4 successive rice crops with the existing practices used by farmers. Average grain yield increased by $0.5 \mathrm{Mg} \mathrm{ha}^{-1}(11 \%)$ and $\mathrm{N}$-fertilizer rate decreased by $5 \mathrm{~kg} \mathrm{~N} \mathrm{ha}^{-1}$ with field-specific management compared to the baseline farmers' fertilizer practice (2).

The increased grain yields and reduced $\mathrm{N}$-fertilizer rates resulted in significant gain in $\mathrm{RE}_{\mathrm{N}}$ and profit. Several factors contributed to the increased efficiency with field-specific management. Farmers' practices typically relied on a large N-fertilizer application early in the season, when the capacity for crop uptake was small, and 1 additional $\mathrm{N}$ topdressing. In contrast, fieldspecific management utilized 2 or 3 topdressings that were applied to achieve greater synchrony with crop demand, and individual doses of preplant or topdressed $\mathrm{N}$ were smaller than those applied by farmers. As a result, mean $\mathrm{RE}_{\mathrm{N}}$ increased from $30 \%$ with farmers' practices to $40 \%$ with field-specific management. On average, across all sites and cropping seasons, profit increased by USD $46 \mathrm{ha}^{-1} \mathrm{crop}^{-1}$ through the use of field-specific management. This gain in efficiency was achieved using prilled urea, which is the most widely used $\mathrm{N}$ fertilizer in Asia, and without major changes in other cropping practices. Spreading N applications more evenly during the growing season probably made the largest contribution to improved $\mathrm{RE}_{\mathrm{N}}$. It would also reduce the risk for environmental pollution associated with gaseous $\mathrm{N}$ losses or losses from runoff and leaching.

These results highlight the potential for improving NUE at the farm level in small-scale farming systems in developing countries. They also demonstrate that such improvements occur in small increments and will require significant long-term investments in research and extension education. Several years of onfarm experimentation are required to develop an "optimal" $\mathrm{N}$ management scheme for a particular location that is characterized by a set of common environmental, socioeconomic, and cropping characteristics. Seasonal variation is large and fine-tuning of $\mathrm{N}$ management must be accomplished in accordance with other management factors that influence NUE such as balanced supplies of macro- and micronutrients, water management, optimal plant density, and pest control (40).

\section{RESEARCH AND POLICY PRIORITIES TO IMPROVE NITROGEN-USE EFFICIENCY}

Although there have been improvements in NUE for some crops (Fig. 1) and in several countries (13-14), concerns about the negative effects of reactive $\mathrm{N}$ load on ecosystem function and environmental quality persist (41). Reliable estimates of $\mathrm{N}$ losses from the major agroecosystems are required to understand the contribution of agriculture to these problems. Here again there are few studies in which $\mathrm{N}$ losses have been measured in onfarm settings across a reasonable range of representative environments; most estimates are based on field experiments conducted at research stations. Although such studies provide useful information about the relative importance of different loss pathways and the biophysical factors controlling them, they do not give accurate estimates of actual $\mathrm{N}$ losses under on-farm conditions. Despite the lack of hard data on $\mathrm{N}$ losses from on-farm environments, nitrate concentration in ground water often exceeds acceptable thresholds and nitrate losses contribute to eutrophication of surface water bodies in many agricultural ar- eas where intensive cropping systems are the dominant form of land use (42). In addition, atmospheric $\mathrm{N}_{2} \mathrm{O}$ concentration has increased rapidly since the 1950 s in concert with the increase in $\mathrm{N}$ fertilizer applied to cropland.

While specific tolerance thresholds for $\mathrm{N}$ losses from cropping systems cannot be determined without more reliable data on hydrology and current levels of $\mathrm{N}$ losses, most agricultural scientists and ecologists agree on a number of issues regarding productivity and environmental requirements of future agroecosystems: $i$ ) food production must increase substantially to meet the needs of a much larger and wealthier human population; ii) nearly all of this increase must come from achieving greater yields on existing agricultural land rather than expanding production to marginal land or by further encroachment into natural ecosystems such as rainforests, wetlands, or estuaries; iii) farmers must achieve significant improvements in NUE to maintain acceptable standards of environmental quality; and $i v$ ) farmers must make a profit to stay in business. Agreement on these issues provides common ground for examining research priorities and policies that foster the tripartite goals of food security, agricultural profitability, and environmental quality.

\section{Research Priorities}

Given continued population growth and limited land resources, a strong emphasis should be given to understanding and improving NUE in the major cereal cropping systems that are endowed with good soils and climate and can support both high yields and high NUE based on the biophysical principles governing $\mathrm{N}$ supply and crop demand. Indeed, the challenge of sustaining adequate rates of gain in cereal yields while significantly improving NUE must receive explicit emphasis in the global research agenda. The magnitude of this challenge should not be underestimated for 4 reasons: $i$ ) crop physiological $\mathrm{N}$ requirements are tightly conserved as determined by photosynthetic pathway and grain $\mathrm{N}$ concentration (Figs. 1 and 2); ii) the yield response to crop-N accumulation is curvilinear (Fig. 3); iii) increased yields require greater $\mathrm{N}$ accumulation (Fig. 3), which in turn requires a larger pool of plant-available soil-N to support additional crop growth, but which is also more vulnerable to $\mathrm{N}$ losses from all pathways; and $i v$ ) the plant-available soil-N pool is highly variable (Fig. 4) and difficult to predict.

While it has been argued that application of existing technologies can meet much of the needed improvement in on-farm NUE, we believe such assessments are too optimistic because they are based on overestimation of current levels of on-farm $\mathrm{RE}_{\mathrm{N}}$ and they assume increased inputs from nitrogen-fixing legumes (43). Increased $\mathrm{N}$ input from legumes to reduce dependence on $\mathrm{N}$ fertilizer is not likely in the developing countries of Asia, where the majority of increased food demand and production is projected to occur, because inclusion of legume crops in cereal production systems has decreased markedly during the past 30 years (44). Diverting land for green manure crops in this region has become uneconomical because land scarcity and wage rates are increasing rapidly. Moreover, green manures used in irrigated rice systems have similar or lower $\mathrm{RE}_{\mathrm{N}}$ than inorganic $\mathrm{N}$ fertilizer $(45,46)$. Although inclusion of grain-legumes in rotation with cereals can reduce $\mathrm{N}$-fertilizer requirements compared to continuous cereal cropping, they generally do not increase soil$\mathrm{N}$ stocks because more $\mathrm{N}$ is removed in harvested seed than is replenished by biological $\mathrm{N}$ fixation. And, despite greater $\mathrm{N}$-fertilizer requirements of continuous maize systems, recent evidence suggests that nitrate leaching is greater in a maize-soybean rotation than from continuous maize (47).

Another scenario for meeting both food needs and alleviating environmental damage from $\mathrm{N}$ used for crop production relies on a projection for a doubling in the rate of cereal yield increase compared to current rates of gain (14). Such a scenario is questionable because the rate of yield gain for the major cereals has 
been declining steadily during the past 30 years (48). In contrast to these rather optimistic scenarios, we view the dual goals of meeting food demand while protecting the environment from excess $\mathrm{Nr}$ as one of the greatest ecological challenges facing humankind.

What, then, are the highest priorities for research investment and policies to improve NUE? A short-list of research targets that are not likely to have a large impact will be considered first. We see little scope for genetic improvement in $\mathrm{PE}_{\mathrm{N}}$ because the relationship between economic yield and crop- $\mathrm{N}$ uptake is tightly conserved. This in turn suggests only marginal gains in $\mathrm{N}$ efficiency from molecular engineering of $\mathrm{N}$ assimilation and biochemical transformation pathways within the plant. Likewise, $\mathrm{N}$ uptake capacity of crop root systems does not appear to be a sensitive factor limiting the efficiency with which most crops acquire soil or fertilizer $\mathrm{N}(4,49)$, especially when compared to potential improvements in NUE from better crop- and soil-management practices. Similarly, we see little biological or economic advantage from organic $\mathrm{N}$ sources over inorganic $\mathrm{N}$ fertilizer when both are used with 'best management' practices because the same biophysical factors govern $\mathrm{N}$ cycling processes regardless of $\mathrm{N}$ source. Moreover, nearly all available animal manure is already used as inputs to cropping systems and the scope for increased inputs from legumes, as described above, is small.

Instead of these less promising targets, we see the greatest gains in NUE and environmental protection accruing from "precision management" in time and space of all production factors to maximize the synchrony between crop- $\mathrm{N}$ demand and the supply of mineral $\mathrm{N}$ from soil reserves and $\mathrm{N}$ inputs in high-yield systems $(27,50)$. Such precision-management approaches will be required for both large-scale agriculture in developed countries and small-scale farming in developing countries. Balancing $\mathrm{N}$ demand and supply will require breakthroughs in fundamental understanding of crop and soil ecology and organic geochemistry to allow development of dynamic and cost-effective N-management approaches. For example, although theoretical predictions indicate significant environmental and economic returns from site-specific N-management in USA maize systems, it has been very difficult to document actual improvements in yields or $\mathrm{RE}_{\mathrm{N}}$ under on-farm conditions (51). This discrepancy between theory and practice results from large gaps in our knowledge of plant response to spatial and temporal variations in soil conditions and in effects on crop response to indigenous and applied N. Similar knowledge gaps limit our ability to utilize remote sensing of plant $\mathrm{N}$ status and simulation models as costeffective and practical tools for improved $\mathrm{N}$ management.

The long-term cumulative "feedback effects" of N and cropmanagement tactics on soil quality also must be considered with explicit emphasis on productivity and NUE of the entire agroecosystem. Soil organic-matter content is a key measure of soil quality in upland cropping systems. Upland soils that sequester carbon also sequester $\mathrm{N}$, resulting in greater indigenous $\mathrm{N}$ supply and a reduction in $\mathrm{N}$-fertilizer requirements. Management practices that lead to increased soil organic matter or alter organic matter composition to achieve better synchrony between soil net-N mineralization and crop demand provide efficiency benefits over the long term $(30,52)$.

Quantitative, on-farm evaluations of improved technologies and measurements of $\mathrm{N}$ losses are needed to provide reliable estimates of potential improvements in NUE in the major agroecosystems. While present knowledge of individual components of the $\mathrm{N}$ cycle and estimates of $\mathrm{N}$ inputs are generally adequate, large uncertainties exist in the magnitude of $\mathrm{N}$ losses from both crop and livestock production systems. Better estimates of losses of specific $\mathrm{N}$ compounds $\left(\mathrm{NO}_{3}, \mathrm{~N}_{2} \mathrm{O}\right.$ and $\left.\mathrm{N}_{2}\right)$ also are needed for major agroecosystems throughout the world. Scientific uncertainties are especially large for net-N immobilization/mineralization rates in systems where soil organic-matter levels are changing over time as a result of increased cereal cropping intensity, higher yield levels, and conservation tillage or residuemanagement practices. Without such data, research investments and policies may not accurately target crucial components of the $\mathrm{N}$ cycle or promote the most cost-effective technologies.

\section{Effective Policies}

While there is a large body of published research on technologies for increasing NUE, relatively few have been adopted by farmers because they are not cost-effective or practical. Adoption of improved technologies typically requires additional skills and labor or investments in new equipment. Information on expected costs and economic returns from such investments is required to convince farmers of the benefits from adoption. The only data directly available to farmers regarding NUE are the grain yield they obtain from their fields and the amount of $\mathrm{N}$ fertilizer they apply. Unfortunately, these data provide little information about the size of the indigenous $\mathrm{N}$ supply, $\mathrm{RE}_{\mathrm{N}}$, or $\mathrm{PE}_{\mathrm{N}}$, all of which are essential for identifying management practices that increase both NUE of the cropping system and economic return from applied N. Farmers also need estimates of the portion of yield obtained from indigenous soil-N and the yield increase from applied N. A more thorough understanding of these NUE components are essential for management decisions that maximize returns from both indigenous and applied $\mathrm{N}$, and which in turn minimizes the potential for $\mathrm{N}$ losses

Because of the cryptic nature of these NUE components, both the public and private sector must play a greater role in providing information to crop producers about how various management and technology options influence these components. Policies must support strong research and extension programs that develop this capacity, especially for cereal-cropping systems that are rapidly intensifying. Policies must also recognize the potential for interactions between different environmental goals. For example, some technologies proposed for decreasing $\mathrm{P}$ runoff from fields that receive applications of livestock manure may increase the potential for N-leaching losses (53).

Low profit margins of most cereal production systems make it difficult for farmers to absorb the costs of environmental regulations. Incentive programs to promote adoption of $\mathrm{N}$-efficient management practices are preferred because regulations imposed on farmers in one country can have the unintended effect of exporting crop and animal production systems with high Nr leakage to countries with the least stringent environmental guidelines. If at some point in the future scientific evidence clearly supports more drastic action to reduce $\mathrm{N}$ load in the environment, a global plan may be needed to concentrate food-crop production in agroecosystems with the highest biophysical potential to maximize grain output in relation to $\mathrm{N}$ losses and the potential for environmental damage.

\section{References and Notes}

1. The term reactive $\mathrm{N}(\mathrm{Nr})$ includes all biologically active, photochemically reactive, an radiatively active $\mathrm{N}$ compounds in the atmosphere and biosphere of the Earth. Thus, $\mathrm{Nr}$ includes inorganic reduced forms of $\mathrm{N}$ (e.g. $\mathrm{NH}_{3}, \mathrm{NH}_{4}^{-}$), inorganic oxidized form (e.g. $\mathrm{NO}_{x}, \mathrm{HNO}_{3}, \mathrm{~N}_{2} \mathrm{O}, \mathrm{NO}_{3}^{-}$), and organic compounds such (e.g. urea, amines, proteins)

Doberm

A., Witt, C., Dawe, D., Gines, G.C., Nagarajan, R., Satawathananont, S., Son, T.T., Tan, P.S., Wang, G.H., Chien, N.V., Thoa, V.T.K., Phung, C.V., Stalin, P., Muthukrishnan, P., Ravi, V., Babu, M., Chatuporn, S., Kongchum, M., Sun, Q., Fu, R. Simbahan, G.C and Adviento, M.A.A. 2002 Site-specific nutrient management for intensive rice cropping systems in Asia. Field Crops Res. 74, 37-66.

3. Cassman, K.G., Kropff, M.J., Gaunt, J. and Peng, S. 1993. Nitrogen use efficiency of irrigated rice: What are the key constraints? Plant Soil 155/156, 359-362.

4. Peng, S. and Cassman K.G. 1998. Upper tresholds of nitrogen uptake rates and associated N fertilizer efficiencies in irrigated rice. Agron. J. 90, 178-185.

Dobermann, A., Dawe, D., Roetter, R.P. and Cassman, K.G. 2000. Reversal of rice yield decline in a long-term continuous cropping experiment. Agron. J. 92, 633-643.

Smil, V. 1999. Nitrogen in crop production: An account of global flows. Global Biogeochem. Cycles 13, 647-662.

Council for Agriculture, Science and Technology (CAST). 1995. Waste management and utilization in food production and processing. Task Force Report No. 124. CAST, Ames 1A, USA. 
8. Cassman, K.G., De Datta, S.K., Olk, D.C., Alcantara, J.M., Samson, M.I., Descalsota, J.P. and Dizon, M.A. 1995. Yield decline and the nitrogen economy of long-term experiments on continuous, irrigated rice systems in the tropics. In: Soil Management: Experimental Basis for Sustainability and Environmental Quality. Lal, R. and Stewart, B.A. (eds). Lewis/CRC Publishers, Boca Raton. pp. 181-222.

9. Paul, E.A., Paustian, K., Elliott, E.T. and Cole, V.C. (eds). 1997. Soil Organic Matter

in Temperate Agroecosystems. CRC Press, Inc., Boca Raton. 401 pp.
10. Olk, D.C., Cassman, K.G., Simbahan, G.C., Sta.Cruz, P.C., Abdulrachman, S., Nagarajan, R., Tan, P.S. and Satawathananont, S. 1999. Interpreting fertilizer-use efficiency in relation to soil nutrient-supplying capacity, factor productivity, and agronomic ciency in relation to soil nutrient-supplying capacity,

11. Jenkinson, D.S. and Smith, D.A. 1989. Nitrogen Efficiency in Agricultural Soils. Elsevier, New York, $450 \mathrm{pp}$

12. Jansson, S.L. and Persson. J. 1982. Mineralization and immobilization of soil nitrogen. In: Nitrogen in Agricultural Soils. Stevenson, F.J. (ed.). Agron. Monogr. 22. American Society of Agronomy, Madison, WI. pp. 229-248.

13. Mishima, S. 2001. Recent trends of nitrogen flow associated with agricultural production in Japan. Soil Sci. Plant Nutr. 47, 157-166.

14. Frink, C.R., Waggoner, P.E. and Ausubel, J.H. 1999. Nitrogen fertilizer: Retrospect and prospect. Proc. Natl Acad. Sci (USA) 96, 1175-1180.

15. van Keulen H. 1977. Nitrogen Requirements of Rice with Special Reference to Java. Bogor, Indonesia: Ministry of Agriculture, Agricultural Technical Assistance Programme. $67 \mathrm{pp}$

16. Sage, R.F. and Pearcy, R.W. 1987. The nitrogen use efficiency of $\mathrm{C}_{3}$ and $\mathrm{C}_{4}$ plants. I. Leaf nitrogen, growth and biomass partitioning in Chenopodium album L. and Amaranthus retroflexus L. Plant Physiol. 84, 954-958.

17. Greenwood, D.J., Lemaire, G., Gosse, G., Cruz, P., Draycott, A. and Neeteson, J.T 1990. Decline in percentage $\mathrm{N}$ of $\mathrm{C}_{3}$ and $\mathrm{C}_{4}$ crops with increasing plant mass. Ann Bot. 66, 425-436.

18. Reddy, G.B. and Reddy, K.R. 1993. Fate of nitrogen-15 enriched ammonium nitrate applied to corn. Soil Sci. Soc. Am. J. 57, 111-115.

19. Cassman, K.G., Gines, G.C., Dizon, M.A., Samson, M.I. and Alcantara, J.M. 1996 Nitrogen-use efficiency in tropical lowland rice systems: contributions from indigenous and applied nitrogen. Field Crops Res. 47, 1-12.

20. Cassman, K.G., Peng, S., Olk D.C., Ladha, J.K., Reichardt, W., Dobermann, A. and Singh, U. 1998. Opportunities for increased nitrogen use efficiency from improved resource management in irrigated rice systems. Field Crops Res . 56, 7-38.

21. Bouldin, D.R. 1986. The chemistry and biology of flooded soils in relation to the nitrogen economy in rice fields. Fert. Res. 9, 1-14.

22. Legg, J.O. and Meisinger, J.J. 1982. Soil nitrogen budgets. In: Nitrogen in Agricultural Soils. Stevenson, F.J. (ed.). Agron. Monogr. 22. American Society of Agronomy, tural Soils. Stevenson, F.J.
Madison, WI. pp. 503-557.

23. Powlson, D.S. 1993. Understanding the soil nitrogen cycle. Soil Use Mgmt 9, 86-94.

24. Jenkinson, D.S. 1990. The turnover of carbon and nitrogen in soil. Phil. Trans. Roy. Jenkinson, D.S. 1990. The
Soc. Lond. B 329, 361-368.

25. de Willigen, P. 1991. Nitrogen turnover in the soil-crop system: comparison of fourteen simulation models. Fert. Res. 27, 141-201.

26. Richter, J. and Benbi, D.K. 1996. Modeling of nitrogen transformations and translocations. Plant Soil 181, 109-121

27. Appel, T. 1994. Relevance of soil N mineralization, total N demand of crops and efficiency of applied $\mathrm{N}$ for fertililzer recommendations for cereals-Theory and application. Z. Pflanzenernahr Bodenk. 157, 407-414.

28. Campbell, C.A., Myers, R.J.K. and Curtin, D. 1995. Managing nitrogen for sustainable crop production. Fertilizer Res. 42, 277-296.

29. Izaurralde, R.C., Feng, Y., Robertson, J.A., McGill, W.B., Juma, N.G. and Olson, B.M. 1995. Long-term influence of cropping systems, tillage, tillage methods, and $\mathrm{N}$ sources 1995. Long-term influence of cropping systems, till
on nitrate leaching. Can. J. Soil Sci. $75,497-505$.

30. Robertson, G.P. 1997. Nitrogen use efficiency in row-crop agriculture: Crop nitrogen use and soil nitrogen loss. In: Ecology in Agriculture. Jackson, L. (ed.). Academic Press, New York. pp. 347-365

31. Stivers, L.J. and Shennan, C. 1991. Meeting the nitrogen needs of processing tomatoes through winter cover cropping. J. Prod. Agric. 4, 330-335.

32. Kessavalou, A. and Walters, D.T. 1999. Winter rye cover crop following soybean under conservation tillage: Residual soil nitrate. Agron. J. 91, 643-649.

33. Burns, I.G. 1980. Influence of the spatial distribution of nitrate on the uptake of $\mathrm{N}$ by plants: A review and a model for rooting depth. J. Soil Sci. 31, 155-173.

34. Duvick, D.N. and Cassman, K.G. 1999. Post-green-revolution trends in yield potential of temperate maize in the north-central United States. Crop Sci. 39, 1622-1630.

35. Bundy, L.G., Walters, D.T. and Olness, A.E. 1999. Evaluation of soil nitrate tests for predicting corn nitrogen response in the North Central region. NC Reg. Res. Publ. No. 342, Wisc. Agric. Exp. Sta., Madison, WI. 31 pp

36. Padgitt, M., Newton, D., Penn, R. and Sandretto, C. 2000. Production Practices for Major Crops in U.S. Agriculture, 1990-1997. Statist. Bull. 969. USDA, ERS, WashMajor Crops
ington, D.C

37. Sharpley, A.N. and Smith, S.J. 1994. Wheat tillage and water quality in the southern plains. Soil Tillage Res. 30, 33-88.

38. Cassman, K.G. and Dobermann, A. 2001. Evolving rice production systems to meet global demand. In: Rice Research and Production in the $21^{\text {st }}$ Century: Proc. Symposium Honoring Robert F. Chandler, Jr. June 15-16 2000. International Rice Research Institute, Manila, Philippines. pp 79-100.

39. Wang, G.H., Dobermann, A., Witt, C., Sun, Q.Z. and Fu, R.X. 2001. Performance of site-specific nutrient management for irrigated rice in southeast China. Agron. J. 93, 869-878.

40. Dobermann, A. and Fairhurst, T.H. 2000. Rice: Nutrient Disorders and Nutrient Management. Potash and Phosphate Institute, International Rice Research Institute, Singapore, Makati City 254. pp.

41. Vitousek, P M Aber, J.D. Howarth G.E Likens, G E Mason, P A Schindler, D.W Schlesinger, W.H. and Tilman, D.G. 1997. Human alteration of the global nitrogen cySchlesinger, W.H. and Tilman, D.G. 1997. Human alterati
cle: Sources and consequences. Ecol. Appl. 7,737-750.

42. Knox, E. and Moody, D.W. 1991. Influence of hydrology, soil properties, and agricultural land use on nitrogen in groundwater. In: Managing Nitrogen for Groundwater Quality and Farm Profitability. Follet, R.F. et al. (eds). Soil Sci. Soc. Amer., Madison, WI. pp. 19-5843.

43. Smil, V. 1997. Some unorthodox perspectives on agricultural biodiversity: The case of legume cultivation. Agric. Ecosyst. Environ. 62, 135-144.

44. Ali, M. 1999. Evaluation of green manure technology in tropical lowland rice systems. Field Crops Res. 61, 61-78

45. Becker, M., Ladha, J.K. and Ottow, J.C.G. 1994. Nitrogen losses and lowland rice yield as affected by residue nitrogen release. Soil Sci. Soc. Am. J. 58, 1660-1665.

46. Cassman, K.G., De Datta, S.K., Amarante, S., Liboon, S., Samson, M.I. and Dizon, M.A. 1996. Long-term comparison of the agronomic efficiency and residual benefits of organic and inorganic nitrogen sources on tropical lowland rice. Experim. Agric. of organic and $32,427-444$

47. Klocke, N.L., Watts, D.G., Schneekloth, J.P., Davison, D.R., Todd, R.W. and Parkhurst, A.M. 1999. Nitrate leaching in irrigated corn and soybean in a semi-arid climate. Trans. ASAE 42, 1621-1630.
48. Cassman, K.G. 2001. Crop science research to assure food security. In: Crop ScienceProspects and Progress. Nosberger, J., Geiger, H.H. and Struik, P.C. (eds). CAB International, Wallingford, U.K. pp. 33-51.

49. Kirk, G.J.D. and Solivas, J.L. 1997. On the extent to which root properties and transport through the soil limit nitrogen uptake by lowland rice. Eur. J. Soil Sci. 48, 613621.

50. Cassman, K.G. 1999. Ecological intensification of cereal production systems: Yield potential, soil quality, and precision agriculture. Proc. Natl Acad. Sci. (USA) 96, 59525959

51. Ferguson, R.B., Hergert, G.W., Schepers, J.S. and Crawford, C.A. 1999. Site-specific nitrogen management of irrigated corn. In: Proc. Fourth International Conference on Precision Agriculture, Minnesota, USA, 19-22 July 1998. Robert, P.C. et al. (eds). Amer. Soc. Agron., Madison,WI. pp. 733-743.

52. Witt, C., Cassman, K.G., Olk, D.C., Biker, U., Liboon, S.P., Samson, M.I. and Ottow, J.C.G. 2000. Crop rotation and residue management effects on carbon sequestration, nitrogen cycling, and productivity of irrigated rice systems. Plant Soil 225, 263-278.

53. Heathwaite, A., Sharpley, L. and Gburek, W. 2000. A conceptual approach for integrating phosphorus and nitrogen management at watershed scales. J. Environ. Qual. $29,158-166$.

54. The authors wish to thank Robert Loomis, Vaclav Smil, and Paul Waggoner for their excellent reviews of an earlier draft of this manuscript.

Kenneth G. Cassman is professor of agronomy at the University of Nebraska. He is a systems agronomist who has conducted research on processes governing nutrient cycling and opportunities to improve nutrient management in the major cereal production systems of Asia, North and South America, and North Africa. His address: Department of Agronomy and Horticulture, University of Nebraska, Lincoln, NE 68583-0915, USA

E-mail: kcassman1@unl.edu

Achim Dobermann is associate professor of soil science at the University of Nebraska. He is a soil fertility and nutrient management specialist who has conducted research on soil variability, processes governing nutrient cycling and sitespecific nutrient management in the major cereal production systems of Asia and North America. His address: Department of Agronomy and Horticulture, University of Nebraska, Lincoln, NE 68583-0915, USA.

Email: adobermann2@unl.edu

Daniel T. Waters is professor of soil science at the University of Nebraska. His research emphasis has been the study of nitrogen carbon cycling in intensively managed agroecosystems. He has conducted research in the major cereal systems of north and Central America and Southern Africa. His address: Department of Agronomy and Horticulture, University of Nebraska, Lincoln, NE 68583 0915, USA.

E-mail: dwalters@uninotes.unl.edu 